\title{
Is Information Power? Comparing Anonymous and Open Egg Donation
}

\author{
by Amy Speier
}

\author{
University of Texas at Arlington
}

Sociological Research Online, 22 (2), 1

$<$ http://www.socresonline.org.uk/22/2/1.html>

DOI: $10.5153 /$ sro.4294

Received: 3 Apr 2017 | Accepted: 19 Apr 2017 I Published: 31 May 2017

\begin{abstract}
Both the Czech Republic and the United States are destinations for cross-border reproductive travellers. For North Americans, including Canadians, who opt to travel to the Czech Republic for IVF using an egg donor, they are entering a fertility industry that is anonymous. This makes the Czech Republic different from other European countries that necessitate open gamete donation, as in Austria, Germany and the United Kingdom. For reproductive travellers coming to the United States for fertility treatment, there is a wider menu of choices regarding egg donation given the vastly unregulated nature of the industry. More recently, professionals in the industry are pushing for 'open' egg donation.

For intended parents traveling to either location seeking in vitro fertilization using an egg donor, they must choose whether or not to pursue open or closed donation. As pre-conception parents, they navigate competing discourses of healthy parenting of donorconceived offspring. They must be reflexive about their choices, and protective when weighing their options, always keeping their future child's mental, physical and genetic health in mind. Drawing from ethnographic data collected over the course of six years in the United States and the Czech Republic, this paper will explore both programs, paying special attention to the question of how gamete donation and global assisted reproductive technologies intersect with different notions about healthy pre-conception parenting.
\end{abstract}

Keywords: Egg Donation, In-Vitro Fertilization, Anonymous/open Donation, PreConception Parenting, Disclosure

1.1 The Czech Republic and the United States are destinations of cross-border reproductive care. This special issue attempts to merge studies of parenting culture with studies of assisted reproductive technologies. As Faircloth and Gürtin (2017) write, the pressure for parents to model healthy, reflective, and protective parenting extends to those intended parents who are hoping to create a family by traveling abroad for IVF using an egg donor. This article contrasts two competing models of egg donation: an anonymous/closed model in the Czech Republic and an open model in the United States, for preconception parents who must anticipate and weigh various, often conflicting concerns about raising a healthy child conceived by using an egg donor. This article interrogates the ways in which professionals frame anonymous or open donation for intended parents. Czech clinics offer anonymous gamete donation. Accordingly, they urge parents to minimize the role of the egg donor. On the other hand, North American advocates of open donation urge parents to avoid secrecy for the sake of the family. Healthy pre-conception parents must weigh various possibilities in an attempt to 'predict and prevent any circumstance that interferes with normal development' (Faircloth and Gürtin Current Issue).

1.2 Cross border reproductive care entails multiple global routes of people, technologies and genetic material crossing national borders in the pursuit of creating a family using assisted reproductive technologies (ARTs). Intended parents, who may be single, or homosexual or heterosexual couples, travel in search of reproductive technologies including in-vitro fertilization with the use of an egg donor and/or surrogacy, either because they cannot afford treatment in their home country or because regulations restrict their access to technologies readily available elsewhere. 
The Czech Republic is a large hub of cross-border reproductive care, offering fertility treatment to patients from all over the world. The Czech reproductive medical industry has been expanding rapidly over the past decade, as it continues to broaden its services to treat foreign groups of intended parents. Czech legislation regarding gamete donation stipulates that egg donation must be voluntary and anonymous. This distinguishes the Czech Republic from other European countries that push for open donation. The Czech reproductive medical industry relies heavily on a large pool of Czech egg donors. Despite its prohibitive costs for ARTs on the other side of the Atlantic, the United States remains one of the main destination sites for reproductive travel. Treatment in the United State's 'baby business' (Spar 2013) can range from $\$ 25,000$ to over $\$ 100,000$ per cycle, depending on various factors. Intended parents from countries that prohibit third party assisted reproduction or deny access based on sexuality or marital status can be considered 'procreative outlaws' (Martin 2014: 9) as they travel to the United States to create a family.

1.4 In this article, I pay close attention to the Czech and American laws and regulations regarding egg donation. Czech doctors and some Czech egg donors insist that a closed, anonymous donation is best for all parties. In the United States, there is a lot more variation given the laissez faire attitude about regulations (Martin 2014). Thus, there are programs that mirror the Czech model of closed donation. However, in the United States, there are many mental health care professionals, surrogacy and egg donor agency professionals, and reproductive endocrinologists who have an agenda that mirrors the adoption movement which transitioned from a closed system to an open system in the 1980s. Some programs insist that 'open' egg donation is the best avenue for all parties involved.

1.5 The closed system in the Czech Republic, and the open agenda in the United States hinge on different notions of what it means to be a healthy pre-conception parent. Debates have come full circle from the notion that anonymity protects the nuclear family to a focus on a child's right to know of his or her own genetic identity (Strathern 2005: 31). This article will explore both programs, paying special attention to the question of how gamete donation and global assisted reproductive technologies intersect with different notions about healthy preconception parenting.

\section{Literature Review}

2.1 As Faircloth and Gürtin's succinct introduction to this special issue argues, scholars have engaged with the proliferation of parenting culture studies, an effort to understand 'how normative and moralistic expectations around reproduction create individuals who need to be ever more reflexive and accountable for their reproductive actions and decisions' (2017: 2). There has been an increase in expert-dominated discourses about the proper, healthy way to parent children. For those who use assisted reproductive technologies to create a family, they have become 'pre-conceptive parents' who must 'predict and prevent any circumstances that interfere with normal development' (Faircloth and Gürtin 2017). The anxiety that is associated with wanting to be healthy parents now extends to decision making during a cycle of in-vitro fertilization. As intended parents weigh several options, such as open or closed gamete donation, they must do so reflexively and thoughtfully with the best interests of their future children's mental and physical health in mind.

2.2 Scholars of assisted reproductive technologies have written about infertility and assisted reproductive technologies through the lens of medicalization, feminism, kinship, and ethics. Infertility has become an illness to treat with the use of assisted reproductive technologies. In addition, infertility is a stigmatized condition, often shrouded within various layers of secrecy for those suffering from it (Goffman 1969). For those intended parents who turn to in-vitro fertilization in their attempts at creating a family, they must wrestle with ways to normalize their family created with technological assistance (Becker 2000). There is a lot of 'emotional work involved in coping with the demands of the IVF procedure' (Franklin 1997: 121). Given the 'cultural ideology of continuity', intended parents must rethink ways they can connect to their children, as those who pursue adoption also must do (Becker 2000:230). Even further, for intended parents who choose to use an egg or sperm donor, they need to engage even further with ways to naturalize or normalize their families.

2.3 In her seminal study of experiences of infertility and undergoing in-vitro fertilization in the United States,

Becker noted a contrast in ideas about sperm and egg donation, linking the contrast to gender ideals (2000). Similarly, Almeling conveys the ways that gendered norms influence a more altruistic rhetoric surrounding egg donation (Almeling 2007). 'Donors are expected to embody middle class American femininity' (Almeling 2007: 327). Building on her work, much of the debate regarding open or closed gamete donation focuses mainly on egg donation rather than sperm donation. Historically, donor insemination has been concealed, while egg donation has been characterized as something that is more 'open' (Becker 2000: 133). 
Charis Thompson has written about the ways that assisted reproductive technologies in the United States indicated a shift from a child-centered approach to a parent-centered focus on their reproductive rights to pursue in-vitro fertilization (2005: 6). Over a decade ago, intended parents using assisted reproductive technologies were traditionally protected by rights discourses to reproductive privacy (Thompson 2005: 7). She argues, 'the intention to parent predominates' (2005: 24). Her work considers the ways that fertility clinics routinize, normalize and naturalize assisted reproduction.

2.5 However, over the past decade the United States has begun to see a movement toward a more childcentered approach in ethical conversations about egg donation. A 'right to know' discourse pervades Western bioethics (Konrad 2005: 28) whereby the 'rights' of the child are weighed against the rights of parental privacy. A child's 'right to know' is deemed a moral right, particularly with respect to their genetic history and the belief that genetic information is central to one's future health (Konrad 2005: 87). Konrad discusses the way that telling the 'truth' about genetic disease is often presented as a reflexive process.

2.6 In addition, Konrad writes about the moralities of information disclosure between family members concerning genetic diseases (2005). These moralities 'generate dilemmas over what knowledge is "good" to know and what knowledge is "bad" to share with others' (2005:4). Indeed, genes bind relatives to one another (2005). Similarly, intended parents who are using an egg donor must wrestle with moralities of information sharing with future offspring. They must decide whether or not they will tell their donor-conceived offspring that they used an egg donor. If they decide they will disclose to their children, they must also decide when to tell them and how to tell them. In fact, Konrad said it would be 'crucial for further policy ethnography and analysis in this area to address the ways family planning takes place as the sharing of reproductive dilemmas, and how this involves exchanges of information over time between kin, not only prior to, but long after the birth event' (2005: 143).

2.7 Various scholars have examined competing ethical, legal and moral discourses that pervade representations of assisted reproductive technologies as well as in the ways that people manage their experiences. Intended parents who use an egg donor must anticipate making decisions regarding disclosure. Decisions regarding disclosure are tied to pre-conception parenting desire to raise emotionally healthy children. For those who do not disclose, they may want to maintain a semblance of normalcy (see also Readings et al. 2011: 489). For parents who anticipate disclosing to their future offspring, they anticipate a benefit for their children to 'know' their story (see also Readings et al. 2011: 489) and to show how much they were desired. This paper contributes a critical examination of new discourses emerging that place a donor-conceived child's 'right to know' at centre stage once again. Almeling has written about the ways 'children themselves...have become more vocal about their experiences as donor conceived children' (2011:143). As social scientists delve into phenomenon such as the Donor Sibling Registry, the perspective of these children reclaim centre stage.

This article examines competing discourses of open and closed egg donation through the lens of parenting studies, considering different discourses that intended parents and industry professionals use to frame healthy pre-conception parenting of donor-conceived offspring. Discourses of privacy, self-determination, and the 'right to know' may overlap, or they may conflict with one another. Preconception parents anxiously weigh egg donation, anticipating various obstacles or issues their donor-conceived children may encounter. They must be reflexive, embodying healthy pre-conception parenting skills.

\section{Methodology}

3.1 This paper draws from data collected over the course of six years in North America and the Czech Republic, making it a multi-sited ethnographic account (Marcus 1995). During the summers of 2010 and 2011, I conducted participant observation at two Czech clinics, as well as sites of lodging for North American reproductive travellers (Speier 2016). Over the course of this research, I conducted a total of 30 preliminary surveys with former reproductive travellers and 69 interviews: 29 with reproductive travellers, 10 with fertility brokers, and 11 with Czech clinic personnel. From December 2011 to September 2012, I travelled to Canada and 13 different states within the U.S. to follow up with patients I had met in the Czech Republic. I conducted a total of 19 follow-up life history interviews with North American patients and brokers. Pseudonyms have been used for all informants.

3.2 After conducting that research, I thought it important to understand the supply side of this global care chain. During the summers of 2014 and 2015, I conducted a total of thirty-two semi-structured interviews with Czech egg donors at three different fertility clinics located in Prague, Czech Republic. Our conversations circled 
in on the issue of anonymity: I asked Czech donors whether or not they imagined their recipients, and whether or not they would donate openly.

In February 2016, I began gathering data about international couples traveling to the United States for ARTs. I spent two weeks conducting participant observation and semi-formal interviews with employees of a California company that conducts searches for intended parents seeking an egg donor, a surrogate, or both. Since then, I have met and spoken with dozens of professionals in the industry, including family lawyers, genetic counsellors, surrogacy and egg donor agency employees. To date, I have conducted twenty-seven semistructured interviews with individuals working on the supply side of this industry.

\section{Czech Genetic Block}

4.1 Tom and Hana, the owners of an IVF broker company I call IVF Holiday, promote the anonymity of egg donation as part of their bundled fertility holiday. Tom assumed anonymity would be a strong selling point. For many couples who reach the point of needing IVF with egg donation, the secrecy that envelopes their struggle of infertility may thicken. The desire for discretion for those who are seeking IVF using egg donation has been documented (Inhorn 2003; Becker 2002). Women who have come to the point where they need IVF with an egg donor may need to conduct some 'ontological choreography,' a term that captures the multifaceted struggles intended parents have when confronting possibilities offered by ARTs and their attempts to normalize their paths (Thompson 2005). While some couples may admit to using IVF, they may not tell people about the fact that they are using an egg donor. Tom of IVF Holiday intimated, 'Women are happy that it's an anonymous donor. You don't want to have to worry about someone knocking on your door. They can feel comfortable being in the no-tell camp, knowing that the donor doesn't even know if there is a birth, and the only thing she knows about them is that they exist. They don't know where you're from. They don't know how old you are. You exist. There's a woman out there who wants your eggs, and that's all they know and that's all they ever know.' Even further, the distance between the United States and the Czech Republic may proffer secretive intended parents more protection and privacy.

4.2 Dr. R, the owner of a fertility clinic in Moravia, was the first person I met to suggest a divergence between 'European' (closed) and 'American' (open) philosophies of donation. He said that many North Americans he treats actually prefer 'open' donation so they can meet the egg donor, know more about her, and have a chance of thanking her with a small gift. According to Dr. R, Europeans, unlike North Americans, are not interested in disclosing to their children that they are from egg donation. He wavered only slightly when speaking with me about which program is 'better.' He seemed to intimate that it is not in the best interest to disclose to one's child that s/he is conceived using an egg donor, 'Most Europeans don't want to tell. You are their child. I don't know why, but Americans, if we are talking generally, there are plans to say to my children. I don't know if is it good way or not. I think it's direct way to psychiatric (sic). America it's very modern. Everybody has his own psychiatric work. Not in Europe, but in America there are a lot of very rich psychoanalysts.' Laden in his comment is an assumption that disclosing to one's child that they are donor conceived will lead to psychological issues for that child. It would be an unhealthy approach to parenting. It has the potential to mean that donorconceived children will have mental health issues related to issues of trust, understanding themselves, or feeling 'in the dark'. In the United States, there tends to be a need to understand oneself philosophy that leads to more positive associations with openness. This parallels some cases of parents in the UK who think it positive for their donor-conceived children to know their own 'story' (Readings et al. 2011: 489).

4.3 According to some endocrinologists, anonymity is meant to protect the privacy of both the egg donor and the recipient. Dr. S., a reproductive specialist in Atlanta, claimed: 'the anonymity piece is really about the parent. It's about keeping the parent from being a pain in the butt, and harassing the donor. And it's about the donor not harassing the parent.' Hertz has suggested that many single North Americans choose anonymous donation in order to avoid legal risk (Hertz 2006: $x$ ). If the sperm donor is not anonymous, single mothers may fear potential future claims of parenthood by the donor. In addition, anonymous donation reaffirms broader cultural values of anonymity and privacy prevalent in North America (Hertz 2006: 65). Early phases of reproductive technology debates claimed anonymity was 'needed to protect the nuclear family, saving it equally from intrusive strangers and the shadow of incest' (Strathern 2005: 31). Those North Americans traveling to the Czech Republic for IVF using an anonymous egg donor may feel relief for these reasons.

4.4 Despite Dr. R's claim regarding European generalizations, the Czech model is only one legal model within Europe. There is a legal trend in Europe discouraging anonymous donation. Austria and Germany have recently passed legislation that ensures children born of gamete donation have access to the donor's identity once they are 18 years old. Czech doctors have steadfastly claimed their laws regarding anonymity are for those 
coming from places like Austria and Germany who do not want to abide by such stipulations. In fact, Czech doctors have suspicions that if they followed this European trend, their segment of the market would crumble. Doctors are literally banking on the fact that the law will remain the same. Dr. R worried: 'I don't know . . But if [donation] will be open, children in the future have the possibility to know [their] donor, it will be problem.' Dr. M bluntly concurred, 'We are done' if a new Czech law stipulates that donation must be open. He claimed patients would simply continue traveling further east to places where anonymity is assured.

4.5 In fact, most egg donors are unaware that their eggs are donated to foreign clients. I asked Dr. M if Czech egg donors know the number of foreign couples coming to Czech clinics. He claimed that possibly half of them know. However, since it is anonymous, he is not at liberty to share with them any information. Dr. M said that those egg donors who do know are usually happy that their eggs were given to a foreign couple, since this lessens the chance of children with the same genetic makeup meeting. Jana, an IVF coordinator for North American patients in Brno, assumed that most donors do not know their eggs are going to foreign couples, but also claimed they probably do not care.

4.6 I asked Czech egg donors if they thought about their recipients at all. Many of them said they do not. Adriana was the first egg donor I interviewed, and we spoke out on the balcony of a clinic on the outskirts of Prague. She told me, 'I also have to sign a document that I can't look for her at all. So I don't know anything.' She immediately ended with a phrase I would hear many times 'Je to lepsi' - It is better not to think of the recipients. Some women said they did not want any information, others said vaguely that they are happy they helped someone. Some hesitated when answering the question of whether they thought of recipients, indicating a possible gap between clinical philosophy and their own thoughts. Marika, a married mother of a six year-old and a three year-old said, 'I do not preoccupy myself with that.' However, I interpret this as a regurgitation of the clinic's claims about the positive aspects of anonymity. Some Czech donors I met also hoped that their recipients were from far away, another country, so that there would be little chance of encountering the child in the future. The mindset that seems to be promoted by clinics is that any information could be dangerous. The assumption is that pre-conception parents and egg donors should simply forget about the fact of egg donation in an attempt to resume a typical life course.

4.7 Nevertheless, even after Adriana said that it is better to not know who her recipient was, she said she would still donate if it were not anonymous. Many of the Czech egg donors I met, even if they had said that it is 'better' not to know, still thought that they would still donate if the Czech laws allowed for open donation. Some thought it would be better. Natasha, for example, was a divorced mother of three who was from northern Bohemia. She said, 'Yes, not that I would want the baby, but I would be interested to know if it's a boy or a girl, if he or she is healthy.' She actually preferred an open donation, thinking, 'It's nice to know whom you can help. I know that certainly you don't have any right to the child because the parent is the one who gives birth to the baby, but some information - if everything is all right, if the baby is healthy, getting a picture once a year, that would be nice.' So it seems in some cases with Czech egg donors, they would prefer a little more information. It does not mean that she wants parental rights, but information about the children would be welcome and appreciated. As it stands, donors do not even know the outcome of the IVF cycle, whether it resulted in a live birth or not. They simply want to know they helped produce healthy children.

4.8 Just as some Czech egg donors wanted more information, some intended parents who travelled to the Czech Republic felt in the dark at times. Angela, whose father had been a university professor, was one of the most direct Americans I met over the course of my research. She told me how she kept telling Tom (of IVF Holiday) her biggest fear before her trip. She said to Tom, 'I don't want a Marty Feldman baby.' She continued:

\footnotetext{
That's my only fear, is that the doctors over there are rubbing their hands together going, 'Ah these naïve Americans, here comes another one.' Bring in Helga with the crazy eyeballs, 'Let me drop the egg, okay here comes the sperm. Very good, we have another one now'... I'm like, 'What am I doing?' That's what I said to Chris (her husband), 'What am I doing?' Going to this country, I've never been there, I know no one, and I'm just trusting unknown people to pick some random woman's eggs that I'm going to allow to just like be put inside my body with my husband's sperm. Ah, it's so weird.
}

4.9 Angela could only reconcile herself with egg donation if there was a resemblance: 'If I'm going to be carrying this baby, I think it would feel a little better if I knew there was some kind of resemblance.' The fear of a 'Marty Feldman baby' reveals the stress and angst involved in placing one's trust in such procedures with a foreign clinic where gamete donation is anonymous. Intended parents coming from North America may feel powerless under Czech medical care and its lack of transparency. 
4.10 Since many couples that use an egg donor hide this fact, they are hoping to model their family after nature, 'passing for kinship' (Bergmann 2012: 351). Secrecy is a strategy to manage 'the genetic identity of their children' (Haimes, cited in Nahman 2013: 196). Secrecy protects 'the idea of the family' (Haimes 1993a: 178). It was apparent to me while conducting this research that there was great variability in terms of how North Americans thought about disclosure, and it was tied to stigmatization, or the 'undesired differentness from what we had anticipated' (Goffman 1963:5). Sandelowski has written about the ways that 'infertile women experience a profound sense of otherness' (1993:35), and Becker has written about the stigma of male infertility 2002). Infertile couples who have experienced the stigma of infertility are sensitive to the possible stigma their offspring may face as donor conceived offspring. As pre-conception healthy parents, they want their potential children to feel 'normal' (Readings et al. 2011: 489). For example, Juan and Anita did not share with family the fact that they were doing IVF with egg donor. Anita worried, 'The reason why we don't say nothing (sic) is because I don't want my child to grow up and they say, "Well they're not your real parents." I don't want them hurting my child, because that is my child regardless whether it's donor or not. They're my child because I'm the one who raises it. That's my decision, my personal life.' Here, in explaining her nondisclosure to her friends and family, Anita is emphasizing her role as social mother. This is similar for those couples adopting who must 'untie the blood' (Sandelowski 1993). In fact, nature is now 'a site that can be thoroughly assisted by human intervention' Gibbon and Novas 2008: 3). Anita is also acting protectively as a pre-conception mother to her child, hoping to shelter it from potential stigma. She is imaginatively embodying an intensive, protective mother (Hays 1996).

4.11 Pre-conception parents anticipate the potential stigmatization their child may face if it becomes public knowledge that the family is 'abnormal.' If couples have hidden the fact that they used egg donor behind the cloak of their European vacation, then they will try to keep that fact hidden forever. Couples factor in the work and the money they spent in their efforts to build their families in making the decision whether or not to disclose to their children their conception using egg donation. Many couples discuss the fact that their children would not have been conceived without their hard work (Strathern 2005:56). Claudia, of Seattle, said to me over a salad and appetizer we shared at a hip restaurant near Green Lake: 'I don't want a lot of people to know about egg donation at this point. I went through a lot to have him, and I gave him life. I mean, I carried him, having him.' The logic seems to be that Claudia earned a right to motherhood through her many attempts to get pregnant and her difficult birth. She feels that disclosure of the fact that she used an egg donor would violate her claims of motherhood to her son, who may put primacy on the genetic tie to the egg donor or want to seek her out in the future.

4.12 I did meet couples that fit Dr. R's characterization of North Americans as 'open.' If a couple had been open about their infertility journey to the Czech Republic, then they tended to continue in their openness with their child. For those couples that do choose to disclose the fact of donation to their children, they must decide at what point they will tell their child (see alsoNelson, Hertz and Kramer 2013; Readings et al. 2011). A doctor in Prague said that for those who do intend to tell their children, they will probably wait until they are 25 years old, and will not tell them when they are young. Actually, some North Americans I met are telling their children their conception stories when they are very young. Amazon sells books that can be individualized according to the method of conception and birth. Maria told me, 'I did see some little books that explains how you were made. You can order them regular, all natural, or IVF. You can order them all kinds of ways, they're really cute.' When I was following up with Linda and Michael, Linda pulled out her book (Nadel 2007) to show me, having also been recommended the book by Maria:

\footnotetext{
I found this great book. I read it to them; they have no clue. I tell them the story. I figure if I start now, by the time they do have a clue, they'll actually get it. I figure if I start now, they'll have it all engrained. I tell it as a fairytale: Mommy was your tummy big? It's a story about the elephant and they go to the doctor. They have all these tests; she took all these medicines and no baby elephant; no baby came. You talk about the donor, a nice lady elephant with a beautiful hat, and she gives an egg. It's not the kind of egg you eat, because the baby asks that. No, this is a very special egg, and you put it together with daddy's cells and into mommy's tummy and it grows and it grows and it grows and that was you. So it's this really cool thing about donating.
}

4.13 In reading this book to her twins almost daily, Linda is attempting to normalize their conception. By reading this story to them, she is giving her children a point for self-identification, to instill a healthy acceptance of egg donation. However, if her children become more curious or want to meet their Czech egg donor, they may not have that option in their future.

4.14 In fact, Suzanne, a Canadian doctor, had no doubt she would tell her daughter she was conceived using an egg donor. She did, however, worry that she did not have a lot of information about the egg donor: 'We'll definitely tell her, because everybody knows. So the chances of her finding out at some point are really quite 
high. For me, that's the biggest thing that I worry about now: How she's going to react when she finds out? Especially that we'll have to tell her that we don't know what her mother looked like or who she was or anything.' Thus, these parents have very limited knowledge to even share with their donor-conceived offspring, even in cases of full disclosure. They may also worry of potential frustration or sense of loss for their potential children (see also Readings et al. 2011: 489). Suzanne did take comfort in the fact that she had the same egg donor for her two children, so there would be a 'connection' between them. Connection, genetic here, is rendered as important for a healthy childhood. Pre-conception healthy parents emphasize their role as social parents, yet also maintain slight ambivalence and may feel emboldened by their children's shared, albeit anonymous, donor. Her children's potential feelings of ambiguity or loss, since they are shared, may ease any potential suffering that comes from a lack of information.

\section{'Open' Americans}

5.1 I have been struck many times as I venture into America's reproductive travel industry by some of the similarities as well as differences from what I witnessed in the Czech Republic. Just as Dr. R. painted broad strokes in his comparison of European and North American models, many North Americans I met drew similar comparisons. A family law attorney based out of Los Angeles contrasted the EU, which is about the rights of the child, and the United States, which is about people having procreative rights. In her sociological examination of reproductive travel in the U.S., Martin quotes a physician who, like Dr. M. in the Czech Republic, compared North America and Europe: 'ethics in the United States centre on the individual whereas Europe focuses on the collective' (2014: 110). Even further, the United States operates 'in the social, political, and moral context of liberal U.S. values, which holds that individuals should have the right to sell and purchase products and services without government interference' (2014: 61).

5.2 Within the U.S., regulations regarding gamete donation and surrogacy vary state by state. Some I met contrasted ideologies of the East and West Coast, claiming that the East coast is more 'old school' and that they push for more closed programs, whereas the West Coast is more open, although it remains very mixed throughout the country.

5.3 Following on the heels of the open adoption movement, which has become standard, many involved in the reproductive medical industry of the Northwestern part of the United States were lawyers that had actively promoted open adoption, and who in turn actively promote open donation/surrogacy. As mentioned earlier, North America's laxness in terms of regulations for reproductive technologies means that intended parents may choose an open or closed program with variations. There is, however, an agenda of many professionals who are pushing for openness, which will be the focus here.

5.4 Martin labelled the United States an arena of 'laissez-faire' ideology, which insists individuals have the right to make decisions about building a family (2014). Martin notes an overlap in reproductive and bodily autonomy (2014:129). Thus, those working in the fertility industry champion the rights of intended parents to use resources to build a family, and the bodily autonomy of egg donors and surrogates to sell their reproductive labour and body parts (2014: 129). Many conversations that I had with people who worked in this industry confirmed Martin's claims, particularly when they abstained from offering a point of view regarding open or closed programs. I heard over and over how it is a 'personal' or 'individual' matter, and 'there is no right answer'. Despite the frequent times a professional would abstain from proffering an ethical stance, I found myself crawling further into a rabbit hole of potential ethical conundrums and cases that may arise. I began to understand the general wariness of asserting any steadfast opinions.

5.5 I became interested in learning about what intended parents were seeking in their quests for conception to the United States. During my first interview with Marilyn, a young Asian American woman who was a former nurse, I asked what criteria most intended parents cared about. Expecting her to rattle off intelligence, good looks, or ethnicity, I was surprised to hear her say, 'For some people the most important thing is that the donor is willing to be contacted.' When I asked for clarification, she continued, 'I caution them that you can't legislate that requirement. Certainly, everybody can go into it [on] good faith, but you can't really legislate it. You can't make them have a relationship. You don't know what's going to happen in their [the egg donor's] life, so you just have to go into it knowing that. It seems like amazingness but sometimes it isn't always amazingness, and so you have to be prepared for the pros and cons, [while] not diminishing that as a viable thing to want.' Aware of the inability to 'regulate' this preference, Marilyn quickly segued into an example of potential pitfalls for intended parents in cases of open egg donation: 'Interestingly enough, in some other countries that are open ID, it means that the donor has rights over the embryos and can veto them being used. So you could do a cycle in the UK and you can have embryos left over, and the donor can say, "I got married, my new husband is not on board with this. You 
can't use those embryos".' She continued by saying that the benefit of doing treatment in the United States is the possibility for contracting with the egg donor for such potential instances.

As was the case in Martin's work (2014), and in the words that Marilyn used in speaking of open donation, many in the industry were wary about pushing for any regulations in the industry. Marilyn continued, 'I don't think that mandating that everybody be open ID necessarily is a good thing.' However, given absent regulations, each case must be contracted with the assistance of an attorney, whose legal knowledge can guide intended parents, egg donors and surrogates through this world of assisted reproductive technologies. Their knowledge is specialized and must be paid for. This means ever expanding expertise regarding healthy preconception parenting can fall under legal authority where each autonomous individual contracts out their intended healthy family, which may include a future relationship between egg donors and the donor-conceived offspring.

5.7 Most North American egg donor profiles are replete with photographs of them throughout their lives as well as members of their family. For intended parents who are seeking an egg donor, the process of 'matching' that happens in the United States differs dramatically from their international competitors (Martin 2014:149). Various metaphors are employed to describe the process. Many have likened matching to online dating, to the horror of some working in the industry. Felicity, the marketing manager for a search company in northern California, explained to me why these metaphors were problematic: 'I don't know, I guess because we are dealing with human beings. I am very passionate about the rights of the egg donors because... I am always a fan of the underdog... Because people view this industry as kind of creepy and don't understand it.' Others have heard the metaphor of real estate, also horrifying. The discomfort these metaphors invoke indicates that they are meaningful and powerful, and it speaks to their importance in how people are framing and interpreting gamete donation within the U.S.'s volatile 'baby business' (Spar 2013).

5.8 I met the owner of an egg donation agency in Los Angeles, Adeline, who talked about the extensive security she maintains for her donor databases to protect their privacy. She explained: 'I think the important thing that we've been starting to add regarding the donors is that we don't put pictures up in other social media websites, because it can be very easy to find you... at least letting them know in advance "hey this technology exists, it's very, very easy to find, and just to be aware if you don't want to be found".' Having been an egg donor herself, like many agency owners, she seems to have the egg donors' interest in mind.

5.9 Many egg donor and surrogacy agency owners were originally donors or surrogates themselves, before deciding to enter this volatile, yet opportunistic market. Adeline talked with me about her own experience of being an egg donor:

\footnotetext{
I ended up being their donor, the woman really wanted motherhood, and I really felt a connection to them. It felt right and it's the best thing I ever did in my life, personally. Many people may not feel that way but that's been my experience. I think if I died tomorrow ... I am so glad that I met those people and somewhere there are two amazing kids ... and I stayed in touch with them.
}

5.11 Former egg donors often employ the word 'connection' to connote a healthy relationship with their intended parents. She clarifies, however, that she wants the donor conceived offspring to have their own privacy and to make the decision once they are adults to meet her:

I don't switch pictures. I saw a few, but I decided until they're older, and if they want them shared, then that's great. But I don't want them to feel privacy violation, and I definitely don't want to meet the child until they're 18. But I have a son, so l'd like my son to meet them. At some point, if they're open to it, I think it would be cool for him to have siblings. So it is at the discretion of the parent. That was my arrangement.

5.12 During our conversation, it was clear that Adeline, like many others, sees the interests of the donor, the intended parents and donor-conceived children as separate. However, she leaves the knowledge and ability to contact with the intended parents, not the children. She quickly turns to talking about the options she offers her clients:

Most choose anonymous. We have a couple different ways we do it. We have the ability to do a phone conversation, where they can talk. It helps a lot of people make a decision for those who are having a hard time getting a sense ... or idea from the pictures. Some donors don't feel comfortable with that. Some will meet in person, and then we will facilitate and we will meet at a coffee shop or we will meet at an office and everybody sits down and how it always works, it is the same way with every client, I send a list of questions and everyone has a chance to look at the list and someone may say, 'I don't like this question, I don't want to answer this'. And I don't allow them to ask other 
5.13 After describing potential meetings between intended parents and egg donors, Adeline admits that many doctors urge an anonymous donation, for the ease of it. However, she claimed, 'I don't necessarily think that's right. I really feel clients should have what [they] need, and donors should have what they need. And if that matches then great, we find a donor.' She continued by talking about the 'rush' that many intended parents are in, and she really pushes them to take the time needed to find a donor that is on the same page. Again, reflexivity about the process is encouraged by egg donor agencies, to be thoughtful about how they envision potential relationships in the future. Endocrinologists, egg donor and surrogacy agency professionals are involved in the ever-expanding discourses of expertise surrounding pre-conception parenting culture.

5.14 Most mental health professionals want things to be truthful, thinking in terms of how difficult it is to keep secrets. For example, one book written about donor insemination is entitled Lethal Secrets (Baran 1999). Dr. S. claims more evenness, depending on the particularities:

\begin{abstract}
I am a little more neutral on this. I wrote a pretty nice review about this whole thing, from the perspective of the embryo donors, and the embryo recipients and the donor conceived offspring, who have not had much of a voice in this. And I describe it as a moral right of the donor conceived offspring, to know their ancestry, pitted against the legal right of privacy of the recipient. Which right wins?
\end{abstract}

5.15 Many informants, like Felicity in California, speak either in terms of the rights of intended parents versus the rights of egg donors. As it is clearly apparent in previous research and broad comparisons made between countries, the procreative rights of intended parents seem to take precedent over the rights of egg donors in North America. Even in the case of anonymous donation, parents may peruse these online profiles of egg donors replete with dozens of photographs and biographical information. Felicity, a British-Canadian woman who worked for the California search company, saw herself as an intended parent advocate, but also one for donors:

\footnotetext{
If I was a young woman, I mean that's where I feel I have a soft spot for the women donors, because the intended parents get to know so much about them and see pictures and find out their transcripts and their SAT scores. Yet how much information do they get about the intended parents? There are some people who would say that they're not obligated to get any of that because they're getting paid.
}

5.16 Here, Felicity is touching upon the debate many have grappled with: how to label egg donation. Should one frame egg donors as givers, employees, laborers, or sex workers? Chloe, a native Californian who worked for the search company, turned to the issue of how little information was afforded to donors: 'It is interesting that the IPs want to know every little thing about the donors, but how much do the donors really know about the IPs?' This question leads us back to the issue of relative power within the reproductive medical industry. Many of the employees of the search company self-identified as advocates for intended parents entering unchartered territory of finding an egg donor. Given the consumer responsibilities involved in being a patient in the United States, they need advocates. However, so do egg donors.

5.17 It seems as if in North America, thinking about ethical issues from the perspective of the donorconceived offspring, who have been 'silent' as indicated by Dr. S. is a newer phenomenon. Becoming more serious, Dr. S. said, 'these psychological concepts become very important. Sometimes the medicine is pretty basic... But to me the part that still has yet to be really discovered and deciphered is that human condition part, that to me is so tricky to work with.' He does not claim to have the answers, which may be less laissez faire and more fraught with recognition of potential complexities.

5.18 Indicating that she could also see from both sides, Felicity quickly switched to the perspective of the offspring, as Dr. S. had. She wondered aloud:

\footnotetext{
Is that (anonymous egg donation) beneficial to the children who are born of this? There's a Facebook group that I'm a member of, though I'm not allowed to post anything. They allowed me to go in so I can see, but it's called Donor Conceived Siblings, Donor Conceived Children. It's a closed group; it's heartbreaking. A lot of it is people born of sperm donation. You know, they're all trying to find their genetic link. I read it because I want to understand what it's like... So people would write, 'My donor was R such and such from New York Cryobank or whatever', so they're trying to find somebody who had the same donor.
}

5.19 Scholars have written about how ethical quandaries often arise on the heels of new reproductive technologies and remain untangled and wrought with various dilemmas, with moving parts of the equation (Martin 2014). Similarly, the healthy parenting project is also ever evolving and moving - in this case into the hearts and minds of pre-conceptive parents. These are potential issues intended parents must mentally confront, receiving 
different and sometimes conflicting advice. Does healthy pre-conception parenting mean being completely open with one's donor-conceived offspring? Will parents have to put aside their wish for secrecy to give their child information about their genetic history?

I met Debbie, the owner of an international egg donation agency, at her home in Atlanta. We sat on her back deck soaking up the southern sun. Over several cups of coffee, we talked for hours about the North American reproductive medical industry. Debbie, unique for employing both North American and South African egg donors, has flown her donors all over the world. Even further, Debbie claimed that the rate of her 'open' donations are at $90 \%$, a much higher rate than other agencies and clinics I met. A former egg donor, like Adeline in LA, Debbie makes sure she provides information and options for her donors. Like Dr. S., in the world of embryo donation, Debbie has pushed for known/open egg donation for several years. She is in contact with most of her intended parents she donated for, and she really tries to explain the reality of having an open donation to egg donors:

\footnotetext{
I know most of my intended parents. I don't keep in contact with them. I don't get Christmas cards, but I feel like that's made me a better egg donor, a better agency... I am happy about my decisions. I don't regret them. I know some day they'll probably come looking for me. I am totally cool with that. I like the open or known, I like the chance for children to be able to know the biological connection. And when I counsel egg donors, I am not a psychologist. There is always this, 'I am not doctor. I am not a psychologist. I am not a lawyer. I am not a tax attorney. But let me just speak to you from experience.' Truly I do a lot of talking, counselling; my knowledge is vast. My intended parents and donors will tell you I am able to guide them in every aspect of this journey, to a very deep degree, but I always have to have that disclaimer. And I think that when an egg donor realizes they want to meet you, even semi-known, you don't exchange contact info. If you decide to exchange contact details, you have to wait twenty-four hours. Both parties have to come to meet. Usually there's one of my staff present domestically and internationally so they have to wait 24 hours because one of the people can change their mind. But just to know and have the opportunity. Egg donors don't understand they don't want you to come for Christmas, they don't want to send you pictures every week. You're not the mother. But someday if the child - if they have questions or want to meet you - that opportunity, they don't have to hire a private investigator and stuff and once you explain it to a donor that way most of them are totally open.
}

5.21 By pushing for open donation, she is opening up the possibility for donor-conceived children to learn about their genetic heritage. She is promoting their right to self-determination. Debbie really sets herself apart from others in the industry when it comes to open donation:

\footnotetext{
I do things that no other agency does, because I believe information is power and information is good. So we create a file, for the potential child, we PDF the egg donor's profile, 17 pages, as it is [at] the time of their donation. If it's an open or known cycle, we send the genetic results, the counselling screening, and the psych evaluation and their medical records, which is against HIPPA. This is international. I have the permission from the donor. I have the request from the intended parent to disclose this information. I create a file and it is for the intended parents to lock away, put it on disc, digital format, paper format, PDF. It's anonymous. We remove the egg donor's name, birth date, take away all the identifying info, but we still give it to them, for them to give the child someday. That's a lot of data that may quell their curiosity. It's photos, there's essay questions, health questions, extended health history, genetic screening of the actual DNA.
}

5.22 Here, Debbie is granting a wealth of information about the egg donor's mental, genetic and physical health. She presents this information sharing as an act of rebellion, but one that may quell future curiosities of donor-conceived children. Preconception parents have a long period of time to wrestle with the decision as to how and when they can share this information.

5.23 Debbie continues to speak about the clauses she has to include in the contracts with her egg donors, stipulating that if the photos are on Facebook or other social media, she cannot guarantee anonymity. Coming back to the conversation I had had with Adeline about her measures to protect donor identity, Debbie's agenda of pushing for open donation seems to align with her realistic assessment of the future. Somewhat similarly, anthropologists have struggled with ways in which they can protect the identity of their informants, laughing at their own meagre attempts decades past (Scheper-Hughes 2001). Debbie foresees anonymous donation as a total impossibility in the future given vague unknowns about potential technologies that may become available. She is entrusting intended parents to be gatekeepers of their children's biological information. Like those intended parents I met in the Czech Republic, they will continually come against competing notions about the proper way for them to disclose to their children their conception stories.

\section{Conclusion}

6.1 In this paper, I have made broad comparisons between Czech anonymous egg donation and American 
open/known egg donation. Both models reflect different ideas about healthy pre-conception parenting of children born via egg donation. In the Czech Republic, the anonymity piece is meant to protect donors and intended parents, their secrecy and their identities. The assumption made by Czech doctors is that their industry depends on reproductive outlaws escaping stipulations that their donor-conceived offspring may contact donors at a certain age. The sacrosanct family that entailed gamete donation in its conception wants to forget about the fact, and to move on within a realm of normalcy. There do not seem to be qualms spoken by Czech egg donors I met, in terms of them seeking future parental rights. However, there were intended parents who will still disclose to their children the fact of their conception, although the amount of information they can offer their children will be limited given the anonymity of Czech law regarding gamete donation. Their children may feel powerless because of the lack of information available, and may turn to new virtual domains that can offer potential answers.

In North America, the laissez-faire attitude rules the unregulated baby business. There is a multitude of parties involved in the process of creating a family using assisted reproductive technologies, including lawyers, mental health professionals, geneticists, agencies and search engines, and of course the clinics. I argue, however, that the laissez-faire attitude may have more to do with the individualized notions of personal liberty and how those notions come to a crossroad when having to contemplate assisted reproduction from the perspectives of different parties. The fragmentation of the reproductive medical industry in the United States means an everexpanding realm of professional expertise when it comes to preconception parenting. Even more, the competing discourses mean preconception parents may feel confusion and ambiguity as they anticipate potential needs, desires, rights of their unborn children. This decision-making process may be fraught with anxiety.

This paper shows a recent trend in the United States of many professionals with an agenda that pushes for open donation as they think about the donor-conceived offspring. These professionals are urging doctors, parents, and agencies to gift donor-conceived children with information about their genetic heritage. Professionals are aware that children may hire investigators, or may conduct image searches online in seeking out their genetic progenitor. They are also assuming that secrets are 'lethal' in any family, and are urging all parties to be 'open'. They are invoking genetic information about one's egg donor to be 'good' knowledge within the moralities of genetic information sharing (Konrad 2005). Entangled within these competing discourses are real families who are struggling to raise donor-conceived children within an intensifying and expanding parenting culture that has enfolded them from their initial foray into in-vitro fertilization. I urge future scholars to turn a critical, compassionate understanding of these donor-conceived children who were raised in new family dynamics.

\section{References}

ALMELING, Rene, (2011) Sex Cells: The Medical Market for Eggs and Sperm. Berkeley: University of California Press.

ALMELING, Rene, (2007) 'Selling Genes, Selling Gender: Egg Agencies, Sperm Banks, and the Medical Market in Genetic Material,' American Sociological Review, Vol. 72, p. 319-340. [doi:10.1177/000312240707200301]

BARAN, Annette, (1999) Lethal Secrets: The Psychology of Donor Insemination, New York: Penguin.

BECKER, Gay, (2002), "Deciding Whether to Tell Children About Donor Insemination: An Unresolved Question in the United States," in Infertility Around the Globe: New Thinking on Childlessness, Gender and Reproduction, Inhorn and van Balen, eds. Berkeley: University of California Press.

BECKER, Gaylene, (2000) Elusive Embryo: How Men and Women Approach New Reproductive Technologies. Berkeley: University of California Press.

BERGMANN, Sven, (2012) 'Resemblance that Matters: On Transnational Anonymized Egg Donation in Two European IVF Clinics,' Knecht et al. (Eds.) Reproductive Technologies as Global Form: Ethnographies of Knowledge, Practices, and Transnational Encounters, Frankfurt: Campus Verlag.

FRANKLIN, Sarah, (1997) Embodied Progress: A Cultural Account of Assisted Conception.London: Routledge.

GIBBON, Sarah and Carlos Novas, (2008) 'Introduction,' Gibbon and Novas (Eds.) Biosocialities, Genetics and 
the Social Sciences: Making Biologies and Identities, New York: Routledge.

GOFFMAN, Erving, (1963) Stigma: Notes on the Management of Spoiled Identity. New York: Simon and Schuster.

Gürtin, Zeynep and Charlotte Faircloth, (Forthcoming) "Fertile Connections: Thinking Across Assisted Reproductive Technologies and Parenting Culture Studies," Sociological Research Online. http://www.socresonline.org.uk/22/2/6.html.

HAIMES, Erica, (1993a), "Secrecy and Openness in Donor Insemination: A Sociological Comment on Daniels and Taylor," in Politics and the Life Sciences, Vol.12, no.2 (August 1993), p. 178-179.

HAIMES, Erica, (1993b) 'Theory and methodology in the analysis of the policy process: a case study of the Warnock Committee on Human Fertilization and Embryology, ' M. Hill (Ed.) New Agendas in the Study of the Policy Process, Hemel Hempstead: Harvester Wheatsheaf.

HAYS, S. 1996. The Cultural Contradictions of Motherhood. New Haven, CT, and London: Yale University Press.

HERTZ, Rosanna, (2006) Single by Chance, Mothers by Choice: How Women are Choosing Parenthood without Marriage and Creating the New American Family, Oxford University Press.

INHORN, Marcia (2003) Local Babies, Global Science: Gender, Religion and In-Vitro Fertilization, New York: Routledge.

KONRAD, Monica, (2005) Narrating the New Predictive Genetics: Ethics, Ethnography and Science. Cambridge: Cambridge University Press.

MARCUS, George E. (1995) 'Ethnography in/of the World System: The Emergence of Multi-Sited Ethnography,' Annual Review of Anthropology, Vol. 24: p. 95-117.

MARTIN, Lauren Jade, (2014) Reproductive Tourism in the United States: Creating Family in the Mother Country, New York: Routledge.

NADEL, Carolina, (2007) Mommy, Was Your Tummy Big?2nd ed., Mookind Press.

NAHMAN, Michael, (2013) Extractions: An Ethnography of Reproductive Tourism, Basingstoke: Palgrave Macmillan.

NELSON, Margaret K., Rosanna Hertz and Wendy Kramer, (2013) 'Making Sense of Donors and Donor Siblings: a Comparison of the Perceptions of Donor-Conceived Offspring in Lesbian-Parent and Heterosexual Parent Families,' S.L.Blair and P.N. Claster (Eds.) Visions of the 21st Century Family: Transforming Structure and Identities. Vol. 13 of Contemporary Perspectives in Family Research, Emerald Group Publishing Limited.

READINGS, Jennifer, Lucy Blake, Polly Casey, Vasanti Jadva and Susan Golombok, (2011) 'Secrecy, disclosure and everything in-between: decisions of parents of children conceived by donor insemination, egg donation and surrogacy,' Reproductive BioMedicine Online, Vol.22, no.5, p.485-495.

[doi:10.1016/j.rbmo.2011.01.014]

SANDELOWSKI, Margarette, (1993) With Child in Mind: Studies of the Personal Encounter with Infertility, Philadelphia: The University of Pennsylvania Press.

SCHEPER-HUGHES, Nancy, (2001) Saints, Scholars and Schizophrenics: Mental IIIness in Rural Ireland, 20th Anniversary edition, Berkeley: University of California Press.

SPAR, Deborah, (2013) The Baby Business: How Money, Science, and Politics Drive the Commerce of Conception. Boston: Harvard Business Review Press.

STRATHERN, Marilyn, (2005) Kinship, Law and the Unexpected: Relatives are Always a Surprise,Cambridge University Press.

THOMPSON, Charis, (2005) Making Parents: The Ontological Choreography of Reproductive Technology, Boston: MIT Press. 
